\title{
PAPER V PRACTICE - EXAMINING THE SCOPE AND LIMIT OF SECTION 206 OF THE LABOUR RELATIONS ACT IN PROVIDING A REMEDY FOR A NON-PARTY TO AN EXTENDED COLLECTIVE AGREEMENT
}

\author{
Jeanne-Mari Retief \\ LLB LLM \\ Extra-ordinary Lecturer, Law Clinic \\ University of Pretoria
}

\section{SUMMARY}

The Minister of Labour may extend collective agreements concluded in bargaining councils to non-parties to the agreements in terms of section 32 of the Labour Relations Act 66 of 1995. The extension of these agreements has long been a cumbersome debate in law and practice. While some argue in favour thereof there are many that argue against it. Non-parties can apply for exemption from these collective agreements, and this is seen as a due remedy, however, the process of applying for exemption can be wrought with inefficiencies. Therefore, the question must be asked whether the employer as a non-party to an extended agreement, has any remedy to its disposal. Section 206 of the Labour Relations Act deals with the effect that a defect or irregularity in a bargaining council can have on the validity of the collective agreement concluded by said council. If the collective agreement is extended to non-parties, and there is a material defect with regard to the collective agreement, this section can provide a due remedy for the non-party, if interpreted and applied correctly. Seen as a clarification for the correct interpretation of section 206 has only recently been addressed in a judgment by Judge Van Niekerk, this article focuses on this interpretation and aims to make certain recommendations with regard to the interpretation of section 206.

INTRODUCTION

In terms of section 32 of the Labour Relations Act, ${ }^{1}$ the Minister of Labour is mandated to extend collective agreements to non-parties within the labour sector. The scope and limit of this mandate and the proper performance thereof has long been an issue of great debate, as the extension of collective agreements to the non-parties has far-reaching socio-economic effects, especially on small and medium business owners that cannot always afford the terms agreed upon in these agreements.

66 of 1995 (hereinafter "the Act"). 
It is argued that non-parties can apply for exemption from the terms of the agreement, and therefore a just remedy is at their disposal. However, the process of applying for exemption can be fraught with inefficiencies, which will be discussed in detail in this article.

Therefore, the question must be asked whether the employer as a nonparty to an extended agreement, has any remedy to its disposal, and whether the provisions in the Act can sustain the envisaged remedy in practice.

Section 206 of the Act deals with the effect that a defect or irregularity in a bargaining council can have on the validity of the collective agreement concluded by said council. If the collective agreement is extended to nonparties, and there is a material defect with regard to the collective agreement, this section can provide a due remedy for the non-party, if interpreted and applied correctly. This article will focus on the validity of the agreement rather than on the correct application of the discretionary power by the Minister.

This article focuses on the metal, engineering and industrial industry, more specifically the metal and engineering industries' bargaining council, ${ }^{2}$ as a backdrop for a very recent and, in my opinion, controversial Labour Court judgment ${ }^{3}$ handed down within this industry, in which Van Niekerk $J$ ruled that section 206 protects a bargaining council from onslaught on the validity of its collective agreement.

In casu the court interpreted the provisions of section 206 to mean that it immunizes collective agreements and acts of bargaining councils as a whole from attacks on their validity. If this judgment is to be accepted, it would mean that regardless of councils' disregard to the rules set out in the Act pertaining to the establishment of bargaining councils, their representation and constitutions, a collective agreement and the subsequent extension thereof will always be valid. Therefore, a pertinent question that flows from this decision is whether section 206 can provide a remedy to the employer.

It must be noted that, although the article will focus on the MEIBC for purposes of the discussion of the judgment, the reader must keep in mind that the judgment can have a meaningful effect on the labour industry as a whole. In lieu of this light will be shed on the practical application issues faced by practitioners with regard to extension, exemptions and the interpretation of section 206.

\section{COLLECTIVE AGREEMENTS}

\section{Extension of collective agreements}

Collective agreements are written agreements that govern and organize conditions of employment and any other mutual interests between

2 Hereinafter "the MEIBC".

3 National Employers Association of South Africa v Minister of Labour (2011) 2 BLLR 198 (LC). 
employees and employers. ${ }^{4}$ Collective agreements are valid when entered into by one or more registered trade unions and one or more registered employers' organizations, or a combination of individual employers and registered employers' organizations. ${ }^{5}$ Collective agreements are binding on all parties that are signatories thereto, including the members of the registered trade unions and employers' organizations that signed the agreement. ${ }^{6}$ These agreements are binding on parties for the entire period they have been entered into regardless of whether members to the employers' organizations or trade unions resign during the lifetime of the agreement, ${ }^{7}$ unless the agreement was concluded for an indefinite period of time. $^{8}$

These agreements are usually binding only on parties to the agreements as set out above, however, in certain instances the parties may request the Minister of Labour to extend the agreement to non-parties to the agreement, which she is mandated to do in terms of section 32 of the Act.

Section 32(1) of the Act provides that a bargaining council may request the extension of a collective agreement if at a meeting of the bargaining council one or more registered trade unions whose members form the majority of employees in the registered scope, vote in favour of the extension, and if one or more registered employers' organizations whose members employ the majority of the employees in the registered scope vote in favour of the extension. This extension may also only be requested if the parties to whom the extension would apply fall within the registered scope of the bargaining council, and are properly identified in the request. ${ }^{9}$

The effect of the extension is that the non-parties to the agreement will be bound by the terms of the agreement as if they were in fact parties or signatories thereto. ${ }^{10}$ This can mean that even though a business is not party to the agreement, it will be forced to give increases in remuneration to minimum-wage workers, whether it can financially sustain the increases or not.

\section{Issues regarding the extension of collective agreements}

The practice of extension of collective agreements has been a problematic one, warped with arguments against it. Seeing that section 32(5)(b) of the Act provides that the Minister may extend the agreement if she is satisfied that the failure to extend such agreement will undermine the promotion of

4 Grogan Workplace Law 10ed (2009) 356; and Van Niekerk, Christianson, McGregor, Smit and Van Eck Law@work (2008) 356.

Ibid;s 213 of Act; and s 1 of the Basic Conditions of Employment Act 75 of 1997.

s 31 of the Act.

Van Niekerk et al Law@work 358.

S 23(4) of the Act.

$\mathrm{S} 32(1)$ of the Act.

10 Grogan Workplace Law 357; s 23 of the Act; and Kem-Lin Fashions CC v Brunton (2001) 22 ILJ 109 (LAC) 117 par [25] and [27]. 
collective bargaining, employers are placed in a somewhat underhanded situation. ${ }^{11}$

The non-parties to the agreement are never asked to make representations in this regard or to raise their opinions as to whether the extension should be granted or not; a government gazette is merely published and that's the end of it. ${ }^{12}$ The broad discretion granted to the Minister in terms of section 32(5)(b) further undermines the employers' options to recourse in this specific regard. As we live in a democratic society, the fact that employers have almost no say in the matter is an extremely bitter pill to swallow. Especially if one takes into account that, although the Minister and collective bargaining bodies are the ones making the decisions, the employers are the ones that have to foot the bill for the increased wages. This in turn places a huge socio-economic burden on especially, small and medium businesses as these smaller enterprises simply cannot afford the high increases they are forced to pay. This leads to the closure of thousands of businesses, which inhibits job creation and places a burden on the growth of the economy. ${ }^{13}$

A further problem created by extension is that there is no real recourse or remedy for the employer that has been subjected to an extension of collective agreements. ${ }^{14}$ Although section 32(3)(e) of the Act provides for an independent body to be established in order to facilitate exemption procedures for employers affected by extension, this remedy can, in my opinion, merely be seen as a pie in the sky or as some sort of consolation prize. In practice this section doesn't truly facilitate the remedy it aims to achieve, as the exemption procedures are fraught with inefficiencies and defects. The problems associated with this remedy are discussed in detail below.

11 See Van Niekerk et al Law@work 359 where they agree that this is a controversial provision as those against extension argue that the extension will inevitably lead to unemployment due to the fact that the employers cannot afford the increases. They continue by stating that this is true in most cases as the small businesses in the industry suffer. The bargaining councils are mostly made up out of larger enterprises that are capital intensive. On the other hand, those that argue in favour of the extensions feel that this ensures stability in the sector.

12 GG 34613 published 2011-09-23 5.

13 "440,000 SMEs Closed in Five Years" March 2012 Business Day http://www.businesslive. co.za/businessexchange/2012/03/12/440000-smes-closed-in-five-years (accessed 2012-0718).

14 In Kem-Lin Fashions CC v Brunton (2001) supra 117 par [23] the court held that "the Act recognizes that there may be cases where subjecting non-parties to a collective agreement concluded in a bargaining council may operate too harshly against them ... the Act precludes the Minister from extending the collective agreement tot non-parties in certain circumstances". Apart from exemption procedures and an appeal board for rejected exemption applications another circumstance is when the Minister feels that the terms of the agreement discriminate against non-parties. This is all theoretically sound, but what is the criteria for measuring whether a non-party has been discriminated against? I would argue that subjecting a host of small businesses to these intensive increases which they cannot afford, without giving them the opportunity to have a say in the matter, would constitute discriminatory action against the non-party. 


\section{Remedies for employers affected by extensions}

Section $30(1)(k)$ of the Act states that a bargaining council's constitution must provide for a procedure for exemption from collective agreements.

Section 32(3)(e) of the Act also requires that the Minister may not extend a collective agreement unless she is satisfied that the agreement makes provision for an independent body to hear appeals brought against the bargaining council's refusal to exempt a non-party from the agreement. In fact section $32(3)(\mathrm{f})$ requires that the collective agreement must contain criteria that the independent body must apply when considering the appeals. ${ }^{15}$

Clause 23 of the main agreement of the MEIBC ${ }^{16}$ provides for exemptions and the procedures to be followed in order to apply for these exemptions. Clause $6(1)(\mathrm{c})$ of the MEIBC's Dispute Resolution Agreement ${ }^{17}$ further provides that should additional information be required from the applicant the council will grant the applicant a 90-day period to comply, after which the applicant will be informed that his/her case has been closed.

The problem with the exemption procedure is that it is a fine theory that has been provided for in legislation and council agreements, but unfortunately that is all it is - a nice theory. In practice this procedure is fraught with inefficiencies. The council does not always respond to the applications within a 60-day period, ${ }^{18}$ thus, should the exemption be denied, employers have to backdate increases, which they couldn't afford in the first place. In my experience with the MEIBC, employers applied for exemption during November 2011, but up until now they have not received any response from the council as to whether the exemption has been granted or not. $^{19}$ One should bear in mind that these applications were for the $2011 / 2012$ increases. $^{20}$ In the meantime the 2012/2013 increases ${ }^{21}$ have come into effect as well. This means that while the employer is still waiting to hear whether he has been exempted from last year's wages, he already has to bring a new application for this year's wages as well. Should the exemption not be granted he would need to back-pay for the $2011 / 2012$

15 See Hofman "Across-the-board wage increases in extended collective agreements: Fair or unfair?" 20093 Obiter 197 202, where he says that the Act does not specify what these criteria need to be. The Act merely requires that it should be "fair and promote the primary objects of the Act”. In Hofman's opinion the latter doesn't mean that any criteria will be acceptable because $s 32(3)(\mathrm{g})$ also has its own fairness requirement and in order for $\mathrm{s}$ $32(3)(\mathrm{f})$ to achieve something it needs to go further than $\mathrm{s} 32(3)(\mathrm{g})$.

16 "Main Agreement" September 2011 http://www.meibc.co.za/images/upload/2011Conditionsof-Employment.pdf (accessed 2012-07-19).

17 "Metal Engineering Industrial Bargaining Council Dispute Resolution Agreement" October 2009 http://www.meibc.co.za/images/upload/DISPUTE_RESOLUTION_AGREEMENT2010. pdf (accessed 2012-07-19)

18 "MEIBC Exemptions Process" http://www.meibc.co.za/images/upload/MEIBC-exemptionsprocess.pdf (accessed 2012-07-19).

19 Although this cannot be said to always be the case, in my experience this is the case with many of the applications.

20 GG 34613 published 2011-09-23 26.

${ }^{21}$ GG 34613 published 2011-09-23 26 32. Please note that a further increase is also set for the 2013/2014 year. 
wages as from September 2011 and he would need to back-pay for the $2012 / 2013$ wages as from 1 July 2012. Apart from the fact that this financial burden will be astonishing, the employee is also suffering in this scenario. Owing to the fact that there is no clarity on the extension of the exemption, employees also don't know where they stand as employers can obviously not pay the increases, which is why they applied in the first place. ${ }^{22}$

Further practical implications were that exemptions were refused on unclear grounds. Financial auditors reported that the employers were indeed in financial trouble and they could not afford the increases. Yet the council still rejected the applications because the unions didn't agree to the exemption. One of the criteria for exemption is that unions should be consulted, an agreement between the employer and the unions should be included, and where no agreement could be reached a statement from the union should be added in which the unions explained why it did not agree to the exemption. ${ }^{23}$ If the employer is to consult with the union the obvious point of departure for the union is to deny lower wages for their members. The union defence is that the company can indeed afford the increases and therefore granting the exemption would be unfair to the employees. This, after the employers have sat down with unions explaining the financial situation of the company, and the obvious dire state they are in. Although the unions cannot be blamed for this, as unions will fight for the best interests of their members, this situation does paint a clear picture of the impasse reached in this scenario.

Exemptions are also provisionally rejected due to outstanding information, but employers don't get a second chance to amend the application as the council will reject the application due to lack of documentation and then summarily close the file and give notice of this in the same letter. This is unacceptable as the Dispute Resolution Agreement ${ }^{24}$ clearly states that employers are to be given 90 days to further comply before a case is closed, yet this is not happening in practice. This situation forces the employers into a position where they have to either re-apply or battle the council over the 90-day period, which also takes up more time.

Even if exemption is granted, employers still need to hand in business plans wherein they set out their proposed method of reaching the new increase rates within the coming two years. In today's economy, a business

22 In National Employers Association of South Africa v Minister of Labour (2011) supra 198 the court held that the facts produced by the respondents indicated no dysfuntionality in the exemption process, even though the applicant contended that it was indeed flawed. The court also held that the most severe consequence of granting the exemption, only to have it withdrawn at a later stage, holds no real threat to the employers as it would basically just come down to paying wages in advance. I respectfully disagree with the latter and submit that seeing that employers were struggling to pay the increases in the first instance it is difficult to believe that they will be able to produce the copious amounts necessary to pay the "wages in advance".

23 Clause 23(2)(c) of the Main Agreement of the MEIBC: "Main Agreement" September 2011 http://www.meibc.co.za/images/upload/2011Conditions-of-Employment.pdf (accessed 201207-19).

24 "Metal Engineering Industrial Bargaining Council Dispute Resolution Agreement" October 2009 http://www.meibc.co.za/images/upload/DISPUTE_RESOLUTION_AGREEMENT2010 .pdf (accessed 2012-07-19). 
that is already suffering cannot be expected to rectify all financial woes in such a short period of time.

There is also a pro forma provided by the MEIBC for a condonation application, which can be brought should an employer miss the cut-off date for application for exemption. Yet nowhere in the agreement is the procedure for condonation applications outlined. Nowhere does it state that one could apply for condonation within a week, or two weeks or three weeks, for argument's sake. This leads one to believe that one can apply for condonation any time one wants to in any fashion one wants.

The above situation in its entirety leads to employers having to retrench on a mass scale as they simply cannot afford the increases, ${ }^{25}$ and they cannot get leave to be exempted. Once again, the theory of the exemption procedure is a good notion, but a good notion means nothing if it cannot be incorporated and sustained in practice.

In light of the all the above it is my opinion that the procedure for exemption, at least in the metal engineering and industrial industry, ${ }^{26}$ is so fundamentally flawed that one can go as far as to say that it cannot provide an appropriate remedy for the employer. If this one remedy cannot be used and enforced, what is the employer to do?

\section{BARGAINING COUNCIL CONSTITUTIONS}

\section{Labour Relations Act}

Section 30 of the Act provides for the requirements for a bargaining council constitution. A bargaining council cannot register as such without a constitution.

In accordance with section 30 of the Act the bargaining council constitution needs to make provision for a host of elements. More specifically, it needs to at least make provision for the rules for conducting and convening a meeting of representatives, the quorum required for such meetings and the minutes that are to be kept of these meetings. It also needs to provide for the manner in which decisions are to be made, the appointment and election of office bearers and officials, their functions and removals. The constitution must also provide for the procedure to be followed in order to be exempted from collective agreements.

These rules governing the minimum requirements for a bargaining council constitution, in my opinion, directly link to the power that a bargaining council has to lodge a request for the extension of collective agreements, seeing as the meeting and the quorum required for the decision for an extension request would need to be provided for in the bargaining council constitution,

25 "440 000 SMEs Closed in Five Years" March 2012 Business Day http://www.businesslive. co.za/businessexchange/2012/03/12/440000-smes-closed-in-five-years (accessed 2012-0718).

26 Although one can argue that in the light of the statements made by Hofman supra, this could be the case in all industries due to the fact that the actual criteria required for appeals to exemption are not specifically set out by the Act. 
and the bargaining council would need to adhere to the precedents set in its constitution. Section 31(1) of the Act reaffirms this notion by stating that a bargaining council collective agreement binds the parties thereto subject to section 32 and the constitution of the bargaining council. Therefore, one can argue that a request to extend the collective agreement as such cannot be valid if it does not adhere to the requirements set out in the constitution of the bargaining council. And for purposes of extension, if it does not adhere to the provisions and requirements set out by section 32 of the Act, it becomes invalid as well.

Furthermore section 32(1) of the Act clearly requires the bargaining council to submit the request only if decided at a meeting of the bargaining council with the due representivity required.

In my opinion, by specifically stating that this decision needs to be made at a meeting, one can argue that this at least needs to be a properly constituted meeting with a properly formed quorum as needs to be provided for in the constitution of the bargaining council in order for the request to be considered valid.

\section{The constitution of the MEIBC}

The constitution of the MEIBC provides for the proper procedure to be followed when conducting meetings. ${ }^{27}$ It also provides for the proper composition of the management committee and it clearly sets out their powers and functions. ${ }^{28}$ According to the constitution the management committee should consist of a president and vice-president, as well as an equal number of members from each of the employees' and employers' party representatives. ${ }^{29}$ The committee will be charged with overseeing all affairs of the council provided that all functions, powers and duties of the management committee will be subject to the direction of the council. ${ }^{30}$

Notices of meetings are to be given that reflect the business to be discussed during these meetings. ${ }^{31}$ These notices shall be given in writing at least two weeks prior to an annual general meeting and at least one week prior to any other meeting. ${ }^{32}$

The quorum for a meeting of the council will be a minimum of fifteen representatives each of the employers and the employees. ${ }^{33}$ The quorum for the meetings of committees of the council is also fully provided for.

These are the basic rules the management committee needs to adhere to, and the basic procedures to be followed during a meeting. Once again as section 32 of the Act states that a decision to request the Minister for

27 Clause 8 and annexure "D" of the MEIBC constitution.

28 Clause 7 of the MEIBC constitution.

29 Clause $7(1)$ of the MEIBC constitution.

30 Clause $7(6)$ of the MEIBC constitution.

31 Clause $8(5)$ of the MEIBC constitution.

32 Ibid.

33 Clause $8(6)$ of the MEIBC constitution.

34 Clause $8(7)$ of the MEIBC constitution. 
extension of a main agreement needed to be reached during a meeting of the council, it follows that the council would need to call a proper meeting that adheres to the rules set out in the constitution of the council.

This, however, was not the case. As agreed to by the MEIBC in an arbitration order, ${ }^{35}$ the management committee that took the decision to request the Minister to extend the main agreement was not properly constituted. In fact the order was issued declaring that since November 2010 no regional council that complied with the MEIBC's constitution existed or currently exists; therefore it was not impossible to constitute a meeting of the council or for the council to appoint a management committee in accordance with the constitution. ${ }^{36}$ It was ordered, that in light of the aforementioned, the annual general meetings held during November 2010 and October 2011 respectively, were not properly constituted in accordance with the constitution. ${ }^{37}$ Therefore, the annual general meeting did not appoint a management committee, and thus no management committee existed during November 2010, neither does this committee exist now. ${ }^{38}$ Finally it was ordered that the meeting held during July 2011 during which the decision was made to request extension from the Minister was not a properly constituted management committee meeting, and that none of the persons who attended the meeting was appointed by the council to the management committee. $^{39}$

I submit that this is a major defect and/or irregularity in the council, as well as a major defect with regard to the representatives appointed. It wasn't an oversight of merely one individual in his capacity as a representative, but by die MEIBC's own submission, it was an entirely defective composition of all representatives that attended. This is not a tiny error to be overlooked and judged as an error of a singular nature. In my opinion this is an entire overhaul of a procedure that has been clearly set out in the constitution.

\section{4 EFFECTS OF DEFECTS AND IRREGULARITIES IN BARGAINING COUNCILS}

Section 206 of the Act deals with the effect that certain defects or irregularities in the bargaining council can have on the validity of the

35 'National Employers' Association of South Africa $v$ Metal and Engineering Industries Bargaining Council" November 2011 http://www.neasanews.co.za/pdfs/Settlement\%20 agreement.pdf (accessed 2012-07-19).

36 'National Employers' Association of South Africa v Metal and Engineering Industries Bargaining Council" November 2011 http://www.neasanews.co.za/pdfs/Settlement\%20 agreement.pdf (accessed 2012-07-19) par 1.1-1.2.

37 'National Employers' Association of South Africa v Metal and Engineering Industries Bargaining Council" November 2011 http://www.neasanews.co.za/pdfs/Settlement\%20 agreement.pdf (accessed 2012-07-19) par 1.3.

38 'National Employers' Association of South Africa v Metal and Engineering Industries Bargaining Council" November 2011 http://www.neasanews.co.za/pdfs/Settlement\%20 agreement.pdf (accessed 2012-07-19) par 1.4-1.5.

39 'National Employers' Association of South Africa v Metal and Engineering Industries Bargaining Council" November 2011 http://www.neasanews.co.za/pdfs/Settlement\%20 agreement.pdf (accessed 2012-07-19) par 1.6. 
collective agreement. In accordance with section 206(1) of the Act a defect will not invalidate the constitution of the bargaining council or a collective agreement of a bargaining council.

However, in my opinion, section 206(2) of the Act goes on to clarify exactly what is meant by the "defect" referred to in section 206(1). The section 206(2) clarification is very specific and very clear; it provides that:

“(2) A defect referred to in subsection (1) means -

(a) a defect in, or mission from, the constitution of any registered trade union, registered employers' organisation or council;

(b) a vacancy in the membership of any council;

(c) any irregularity in the appointment or election of -

(i) a representative to the council;

(ii) an alternate to any representative to the council;

(iii) a chairperson or any other person presiding over any meeting of a council or a committee of a council; or

(iv) the director or a commissioner."

It is my submission that the persistent use of singular words such as "a" and "an" in the wording of section 206(2)(a)-(c), demonstrates that it was the legislator's intent to make provision for minor errors of a singular nature. In other words, if there is a minor defect or irregularity in the council or its constitution, or if merely one representative is absent or not properly substituted, a party cannot bring a legal dispute concerning such a tiny error. This supports the notion that the courts should not be bothered with trivial matters. However, should there be a major defect in the composition of the council, or a major defect in the constitution of the council, section 206 cannot be interpreted to mean that the collective agreement will still be declared valid. In my opinion, there was indeed a major defect in the council during July 2011 when the management committee decided to extend the request to the Minister as none of the representatives present was duly elected to these posts.

\section{NATIONAL EMPLOYERS' ASSOCIATION OF SOUTH AFRICA V MINISTER OF LABOUR ${ }^{40}$}

\section{Brief history}

During 2011 certain parties to the MEIBC signed a collective agreement that aimed to regulate certain conditions of employment. One of the main elements the agreement opted to amend was the minimum wage increase set for the metal, engineering and industrial industries. ${ }^{41}$ The agreement made provision for an increase of $8 \%-10 \%$ during the 2012 year, ${ }^{42}$ a further $7 \%-8 \%$ increase in $2013,{ }^{43}$ and a final increase of $7 \%-8 \%$ in $2014 .{ }^{44}$ This is a significant increase if one takes into account that the entry-level minimum-

40 National Employers Association of South Africa v Minister of Labour (2011) supra 198.

41 GG 34613 published 2011-09-23 5.

42 GG 34613 published 2011-09-23 26.

43 GG 34613 published 2011-09-23 32.

44 Ibid. 
wage for an unskilled employer in the metal engineering and industrial industries is substantially higher than any other industry. ${ }^{45}$ Also note that if an employer is paying his minimum-wage worker more than the required minimum rate, he needs to grant the $8 \%-10 \%$ increases on the current actual amount he is paying his employees. This is a huge problem for employers, as they cannot keep up with the high increases. This leads to a situation where employers never want to pay a cent more than the set minimum, because they fear the increases they would have to produce on the actual amounts they are paying their entry-level unskilled workers. As stipulated in section 31 of the Act this agreement was binding on all parties to the bargaining council who were also signatories to the agreement.

However, during a management committee meeting held in 2011 the council decided to request the Minister of Labour to extend the agreement to all non-parties in this industry. The Minister granted the extension and the agreement came into effect during September $2011 .{ }^{46}$ Concerns were immediately raised by parties to the council that were not signatories to the agreement. It was argued, by the applicants in the National Employers' Association of South Africa-case, ${ }^{47}$ that the management committee that decided upon the request for extension was not properly constituted and therefore the decision to request the extension was not valid. ${ }^{48}$ The applicants referred the matter to the Labour Court, and requested that it be handled as an urgent application, as the extension of this agreement would have harsh effects on this industry and seeing that this industry is one of the largest industries in South Africa, it could well be said that mass confusion would have been created if the extension was granted and then subsequently declared invalid.

\section{Judgment}

In his judgment, ${ }^{49}$ Van Niekerk $\mathrm{J}$ ruled that section 206 of the Act basically protects bargaining-council collective agreements from any and all onslaughts on its validity. He was strongly convinced that since section 206

45 Please refer to the following in order to peruse the industry-wage comparisons: GG 35462 published 2012-06-22 5 which stipulates the minimum hourly rate for an employee in the taxi industry at R8.24; GG 34946 published 2012-01-18 4 which stipulates the minimum hourly rate for farm workers at R7.71; GG 34797 published 2011-11-28 5-6 which stipulates the minimum hourly rate for domestic workers at R7.06; GG 35460 published 2012-06-22 4 which stipulates the minimum hourly rate for employees in the hospitality sector at R11.49 GG 34798 published 2011-11-28 5 which stipulates the minimum hourly rate for employees in the contract-cleaning sector at R12.23; "Motor Industry Bargaining Council Circular" August 2011 http://www.ylps.co.za/mibco-2011-2012-rates (accessed 2012-07-19) which stipulates the minimum hourly rate for employees in the motor industry; GG 33505 published 2010-08-27 4 which stipulates the minimum hourly wage for employees in the civil engineering sector at R18.97; GG 34613 published 2011-09-23 which stipulated the minimum hourly rate for employees in the metal engineering and industrial industries as R28.34. As can be seen by these wage comparisons the minimum hourly rate in the metal engineering and industrial industries is significantly higher than other industries.

46 GG 34613 published 2011-09-23 5.

47 National Employers Association of South Africa v Minister of Labour (2011) supra 198.

48 National Employers Association of South Africa v Minister of Labour (2011) supra par [4].

49 National Employers Association of South Africa v Minister of Labour (2011) supra 198. 
creates this all-encompassing protection, there was no ground for the argument brought by the applicants based on the defects and irregularities in the council when the decision to extend was made. Therefore, the applicants had no existing right to pursue an urgent declaratory order. ${ }^{50} \mathrm{He}$ further stated that:

"It seems to me that s 206 was enacted specifically to protect processes against technical shortcomings and deficiencies in the functioning of bargaining councils. The ordinary grammatical meaning of $s$ 206(1)(b) read with ss (2)(c) immunises collective agreements and acts of bargaining councils from attacks on their validity on account of any irregularity in the appointment or election of any representative to a council, or any of its structures. The applicants' attack on the validity of an act of the bargaining council, at least that part of it premised on the failure by the bargaining council to comply with its constitution in so far as appointments to the management committee are concerned, is precisely the kind of attack envisaged by $\mathrm{s}$ 206."

The court also ruled that section 206 of the Act precludes that even though the council or its management committee was not constituted in accordance with the constitution of the bargaining council at the time the request was made, the request and the subsequent agreement were still valid and protected against onslaught. ${ }^{52}$ In conclusion the court once again confirmed that the appellants had no existing right in which they might have had an interest, and therefore their urgent request for a declaratory order failed. ${ }^{53}$ The Minister's decision was declared valid and enforceable until it is set aside by a court of law. ${ }^{54}$ The court also confirmed that any assertion of any right the applicant might have that was premised on the invalidity of any act of the bargaining council or any irregularity, or any defects did not invalidate the extension of the collective agreements by virtue of section $206 .^{55}$

\section{Critical analysis of judgment}

It is my submission that the interpretation of section 206 of the Act by the court in in casu is flawed, and that a broad interpretation was adopted when in my opinion a narrower interpretation was called for. As stated above it is my submission that the excessive use of the singular in section 206(2) demonstrates that it was the legislator's intent to avoid attacks on the validity of bargaining councils and its agreements in situations where tiny errors of a singular nature occurred. This, as stated above, supports the practice that a court should not be bothered with trivial matters.

However, to interpret section 206 to mean that all bargaining council agreements are absolutely protected from attacks on their validity in all

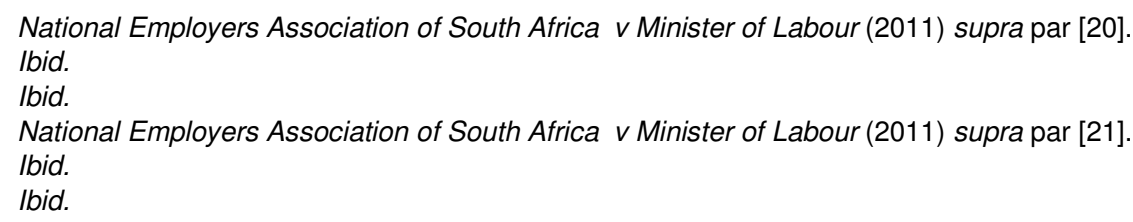


situations due to the existence of section 206 will do harm to the practice of collective bargaining as a whole.

This will cause an effect where an employer will have no recourse if substantial and elemental flaws have occurred. In practice most employers are not even granted the opportunity to raise their opinions about the consequences of the extension of collective agreements, yet they are the ones fishing out the cash to fund these increases. This creates a vicious circle as employers are forced to pay the increases they can't afford leading them to close their doors, which leads to a significant decrease in employment and job creation, which in turn leads to dire consequences for the growth of the economy as small and medium businesses cannot sustain themselves in this harsh environment.

To further limit the right of the employer would mean no objection can ever be raised pertaining to a substantial defect or irregularity in a council or subsequent agreement. Therefore all collective agreements will always be valid no matter the extent and effect of the defect.

In my opinion, if the collective agreement is extended to non-parties, and there is a material defect with regard to the collective agreement, this section can provide a due remedy for the non-party, if interpreted and applied correctly.

It is also interesting that during the arbitration hearing following this case, the respondents admitted that the constitution of the management committee was so defective, that it can easily be said that no management committee even existed when the Minister was requested to extend the agreement. The respondents further admitted that none of the respondents that attended the management committee meeting was appointed by the council to the management committee, and yet the constitution of the MEIBC stipulates exactly how a management committee is to be appointed in order for it to be a properly constituted committee capable of making enforceable and valid decisions on behalf of the council.

If this judgment is to be accepted, it would mean that regardless of a council's disregard to the rules set out in the Act, pertaining to the establishment of bargaining councils, their representation and constitutions, a collective agreement and the subsequent extension thereof will always be valid.

If this judgment is to be accepted, what is the purpose of sections 30 and 31 of the Act? In order to register properly as a bargaining council the council needs to draft a constitution. Section 30 specifically lists the minimum requirements that need to be made provision for in the constitution of the council. Why should there be a constitution at all if the council can disregard the basic provisions required by section 30 at will? Why does section 30 exist at all? I could go on to ask why section 31(1) of the Act has been enacted. Section 31(1) states that a collective agreement is binding subject to the constitution of the bargaining council and section 32 . If the council can once again disregard the rules pertaining to council constitutions in section 30 why would a collective agreement only be binding subject to the council's constitution? 
The insertion of sections 30 and 31 of the Act makes it clear that there are certain rules councils need to adhere to. There are certain requirements for council constitutions, and the binding nature of the collective agreement is subject to the council's constitution. The wording of these sections makes it obvious that a council's constitution is extremely important, and therefore by default, as the constitution needs to provide for it, the correct application of the constitution of the council is imperative. To accept this broad interpretation of section 206 invalidates the existence of section 30 and 31, and I submit that this could not have been the legislator's intent.

\section{CONCLUSION}

In conclusion I submit that the process of extension of collective agreements is a tricky one, with lots of arguments in favour of it and lots of arguments against it. Against the backdrop of this article I submit that this procedure has a lot of inefficiencies that need to be dealt with. In practice is seems that parties affected by the extensions have little say in the matter and only one remedy, which seems to be that of application for exemption and subsequent appeal, should the application be rejected. Although, as discussed above, there can be a lot of practical problems with the exemption procedure which leads much of frustration on the part of the employer. The extension of collective agreements also places a heavy burden on small and medium businesses as they cannot keep up with the high wage increases. In the metal, engineering and industrial industry the wage increases are not the only factor to take into consideration. A host of financial strains exist, as the employer needs to make provision for sick-pay funds, provident funds, and leave-enhancement pay, all of which claim even more money from the employers' pockets.

In light of the above I recommend that section 206 should be interpreted as to avoid onslaughts on the validity of collective agreements in cases where minor errors of a singular nature have occurred. I also recommend that section 206 should not be interpreted as to validate each and every collective agreement across the spectrum, regardless of the defects and irregularities in the council. This would mean that, due to the provisions of section 206, in practice there will be no remedy in law for non-parties affected by the collective agreements extended on grounds where significant defects and irregularities have occurred. This may render the provisions regarding the establishment, representation and constitutional arrangements of bargaining councils worthless in practice with serious repercussions for parties to whom any such agreements are extended where they were not parties to the agreements to begin with. Although this will not provide an across-the-board remedy for all parties to extensions in all situations, this would at least give employers some form of recourse in circumstances where defects or irregularities in councils have occurred during the decisionmaking process. 